\title{
Os mal-amados, de Lourdes Ramalho: tragédia moderna, regionalidade e cultura da honra
}

\author{
Diógenes André Vieira Maciel* \\ Monalisa Barboza Santos Colaço**
}

Das criaturas todas que têm vida e pensam, somos nós, as mulheres, as mais sofredoras.

Eurípides, Medeia.

Resumo: Propõe-se a análise-interpretação da peça Os mal-amados, de Lourdes Ramalho, na qual as representações estéticas carregam resíduos do patriarcado postos em tensão com as tentativas de subverter o domínio masculino, justamente, pelas ações das personagens femininas em vista de novas estruturas emergentes, em meio a uma "cultura da honra". Assim, interpretamse as contradições no plano da forma/conteúdo que enformam esta tragédia moderna, evidenciando, portanto, suas vinculações com a regionalidade nordestina e apresentando este texto a uma nova comunidade de leitores.

Palavras-chave: Lourdes Ramalho. Dramaturgia nordestina. Tragédia moderna. Cultura da honra.

Abstract: It provides an analysis-interpretation of Lourdes Ramalho's play Os mal-amados. In this play, the image of traditional patriarchal society is threatened by the actions of the female characters due to new emerging structures, despite its "honor culture". The way in which the proposed reading depicts these contradictions is characteristic of a Modern Tragedy, evidencing its connection with Northeast Brazilian regionality and presenting the play to a new community of readers.

Keywords: Lourdes Ramalho. Brazilian northeast dramaturgy. Modern tragedy. Honor culture.

\footnotetext{
* Professor do Departamento de Letras e Artes, atuando no Programa de Pós-Graduação em Literatura e Interculturalidade. Doutor em Literatura Brasileira pela Universidade Federal da Paraíba, com estágio pósdoutoral no Programa de Pós-Graduação em Artes Cênicas da Universidade Federal do Estado do Rio de Janeiro. http://orcid.org/oooo-0002-6122-2411

** Mestra em Literatura e Estudos Interculturais pelo Programa de Pós-Graduação em Literatura e Interculturalidade, da Universidade Estadual da Paraíba, onde cursa, atualmente, o Doutorado. http://orcid.org/o000-0003-0620-8809
}

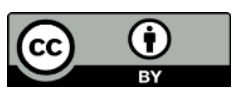

Este artigo está licenciado sob forma de uma licença Creative Commons Atribuição 4.0 Internacional, que permite uso irrestrito, distribuição e reprodução em qualquer meio, desde que a publicação original seja corretamente citada. 
Resumen: Se propone el análisis interpretación de la pieza Os mal-amados de Lourdes Ramalho, en la cual las representaciones estéticas llevan residuos del patriarcado puestos en tensión con los intentos de subvertir el dominio masculino, justamente, por las acciones de los personajes femeninos en razón de nuevas estructuras emergentes, en medio a una "cultura del honor". De este modo, se interpretan las contradicciones en el plan de la forma/contenido que dan forma a esta tragedia moderna, evidenciando por lo tanto, sus vinculaciones con la regionalidad nordestina y presentando este texto a una nueva comunidad de lectores.

Palabras clave: Lourdes Ramalho. Dramaturgia nordestina. Tragedia moderna. Cultura del honor.

\section{Quarenta anos depois...}

Maria de Lourdes Nunes Ramalho (1920-2019) ainda não é uma personalidade artística plenamente conhecida em âmbito nacional, mas não é exagero afirmar que ela é uma referência consolidada da cultura teatral em Campina Grande-PB, e, amplamente, na região Nordeste. Desde 1974, quando estreou a primeira montagem da sua peça FogoFátuo no Teatro Municipal Severino Cabral, levada pelo Grupo Cênico da FACMA Fundação Artístico-Cultural Manuel Bandeira, a dramaturga iniciou a consolidação de um projeto pelo qual buscava equalizar sua experiência docente àquela do teatro, assim chamado, moderno - conforme as tradições italianas e francesas, fortes veios do teatro moderno sudestino, da década de 1940 em diante -, com olhos voltados ao debate sobre o regionalismo marcado pela herança popular, como era bastante potente em Pernambuco desde a atividade do TPN - Teatro Popular do Nordeste. ${ }^{1}$

Hoje já é bem sabido que Lourdes Ramalho buscava encontrar um modo específico de encenar seus textos, ou seja, um modo moderno, pelo qual eles se explicitariam no palco, propondo uma comunicação efetiva com uma plateia que

\footnotetext{
${ }^{1}$ Conforme Nanci Fernandes (2013), diferentemente das práticas do restante do país, haveria uma causa para as diferenças nas tradições regionais, apontando para a moldagem, no Recife, de "um teatro que, nas origens, à diferença do que ocorreu no Rio de Janeiro e em São Paulo, voltou-se predominante para a cultura popular e as tradições locais" (FERNANDES, 2013, p. 77). Nesta proposição, o popular está identificado ao caráter regional do Nordeste - lugar de origem e de destino das raízes da dramaturgia e das técnicas da representação teatral -, distinguindo-se de uma perspectiva popular "meramente política", como, por uma certa interpretação, pode parecer aquela veiculada no Sudeste. Assim, a matéria popular, buscada na pesquisa das formas populares de arte e nos modos de falar do Nordeste, não se limita à representação de um quadro típico, mas à compreensão de especificidades e singularidades estéticas formalizadas tanto na dramaturgia quanto na encenação.
} 
também neles se reconheceriam. Por isso, é bem possível entender que essa tradição moderna não apontava para uma derrocada do texto dramatúrgico, mas para o fortalecimento da encenação enquanto sua raison d'être, já que, nos termos de Brandão (2009), a modernidade teatral estava marcada por uma dupla herança: a francesa, enquanto luta contra o simples comercialismo do, assim chamado, "velho teatro" ou “teatro de atores”, em face do alvorecer de uma nova concepção de diretor, cuja poética se ancorava no texto levado à cena; e a italiana, a qual compreendia o diretor como alguém capaz de empreender a "exata" leitura da obra, gerando um teatro da palavra e um trabalho atoral baseado na interiorização das personagens.

Sendo moderno, o projeto ramalhiano forjou liames entre os grupos de teatro campinenses e a personalidade notável daquela dramaturga, em que as dinâmicas do mercado teatral e dos elencos, atentos ao gosto do público e dos próprios órgãos de fomento, apontavam para a exploração de tudo aquilo o que se vinculasse à representação da regionalidade nordestina como porto seguro estético e comercial. Por estas sendas, Lourdes Ramalho levava ao palco sua percepção em torno da regionalidade, que pode ser entendida enquanto um processo concomitante de criação da "realidade" e das representações regionais - “o imaginário e a construção simbólica moldando o vivido regional e a vivência e produção concretas da região, por sua vez, alimentando suas configurações simbólicas” (HAESBAERT, 2010, p. 8).

Por isso mesmo, esta dramaturga deve ser compreendida enquanto uma autora moderna e atrelada à organização da cultura em sua cidade, em cuja obra eclodia uma marca de nascença, a saber, a pesquisa sobre os falares nordestinos, configurando um, por assim dizer, "estilo esquizofrenicamente dilacerado entre um léxico que procura apanhar a voz do homem pobre da zona rural e a frase correta" (CHIAPPINI, 1994, p. 685). É tal estilo que vai se tornando pertinente aos temas representados em suas obras, dando matéria viva ao teatro moderno produzido em Campina Grande que pode ser, assim, identificado como regional, em consonância aos processos sociais em vigência naquele espaço diante das rupturas históricas, políticas, culturais e econômicas advindas da economia algodoeira decadente e da consequente irrupção de uma imagem de cidade moderna e cosmopolita, muito potente no imaginário local até os nossos dias. 
Compartilhando este imaginário, em que se hibridizavam tradição e novidade, a obra ramalhiana buscava formalizar um modo de olhar, ou melhor dizendo, uma perspectiva sobre o presente, em que se sobressaem aspectos do trágico moderno circunscritos à atmosfera rural permeada por aquilo o que chamaremos, aqui, de cultura da honra.

Por esta trilha é que, neste trabalho, procuraremos analisar a peça Os malamados, escrita em 1976 e estreada em 1977, numa montagem conduzida pelo diretor pernambucano José Francisco Filho, à frente do Grupo Cênico do Centro Cultural Paschoal Carlos Magno, capitaneado pela própria Lourdes Ramalho. Este texto foi escrito tendo em vista um concurso dramatúrgico promovido pela Secretaria de Educação e Cultura do Estado da Paraíba, no qual obteve o primeiro lugar. Todavia, a sua publicação em livro, resultado da premiação no certame, só se deu no ano de 1980, quando apareceu em uma compilação organizada por Alarico Corrêa Neto, intitulada Teatro paraibano, Hoje. Quarenta anos depois, é importante reposicionar o debate em torno deste belo exemplar de dramaturgia brasileira, com o fito de apresentá-lo a uma nova comunidade de leitores, destacando a necessidade de lê-lo e (re)conhecê-lo no ano em que se comemora o centenário de nascimento de sua autora e que verá, em breve, a republicação de boa parte de sua obra, atualmente só encontrável em estantes dos sebos.

\section{Ecos do trágico e feições da honra}

Em Os mal-amados, a ação é nucleada por um conflito familiar envolvendo os Santa Rosa, localizada temporalmente no ano de 1922 e tendo como espaço dramático uma antiga casa de fazenda no sertão paraibano. Desde o início do texto, a autora vai urdindo elementos que apontam para suas vinculações ao trágico, ${ }^{2}$ tendo em conta a forte adesão do enredo e da construção das personagens aos ditames da honra familiar,

\footnotetext{
${ }^{2}$ Ao tratarmos do trágico, temos que considerar que essa palavra se desligou do uso exclusivo à forma grega da tragédia, conforme foi lida por Aristóteles enquanto base para sua poética normativa. $\mathrm{Na}$ discussão em tela, este vocábulo assume função adjetiva, capaz de qualificar uma experiência de vida ou uma visão de mundo, independentemente do modelo genérico em que se encaixe a obra em análise.
} 
de forte base patriarcal, muito cara à cultura nordestina e bastante atrelada ao ethos feminino, enquanto índice de sua subversão e/ou manutenção ${ }^{3}$ - apontando para os vetores de uma cultura da honra, os quais, afinal, regulam (ou contrariam) os acordos que fazem parte de um dado modo de ação humana, a saber, a já aludida honra familiar, além da honra social, da honra masculina e da honra feminina.

Iremos, neste trabalho, pensar como o ethos feminino atua nessa cultura da honra, notadamente no que se refere à regionalidade nordestina. Mas, antes de avançarmos, é necessário que entendamos aquilo o que estamos chamando de vetores daquela acepção cultural. Assim, vejamos: a honra familiar está atrelada a um modo como se entende que a reputação é partilhada pelos membros do núcleo familiar, de modo que a ação de cada um age sobre sua individualidade e sobre a reputação familiar coextensiva, de onde advém a noção de valor e a importância da valorização do "nome" familiar. Em termos complementares, a honra social diz, justamente, dessa interdependência em face dos grupos e dos relacionamentos para além daquele núcleo, nos quais há uma gestão das relações comunitárias pela ênfase naquilo que é marcado por valores bastante internalizados nos indivíduos, como generosidade, honestidade e lealdade, que passam a mediar o indivíduo e o seu grupo. Daí, se chega às implicações de gênero, pois há concepções bem distintas no que se refere à honra masculina e à honra feminina - a primeira diz da capacidade de responder (inclusive pelo uso da força física e imposição de respeito) ao que ofende a ideia bastante normativa de masculinidade, em associação à virilidade enquanto capacidade de defender a honra individual e da sua família; já a segunda, aponta para a suprema "necessidade de manter a castidade sexual, fortemente associada à honra familiar", pois qualquer desvio pode "trazer a desgraça para a reputação da família como um todo" (GOUVEIA et al., 2013, p. 582-583).

\footnotetext{
${ }^{3}$ Temos que compreender que o ethos, em termos etimológicos, tanto indicaria um "espaço protetor", como também um "estilo de vida", um "costume", marcando, assim, "um comportamento que ocorre frequentemente, mas não sempre, tampouco em decorrência de uma necessidade natural" (RIBEIRO; LUCERO; GONTIJO, 2008, p. 126) - ou seja, ao falarmos de um ethos feminino atrelado à honra familiar, devemos aceitar que ele indica um modo constante de agir, dialeticamente relacionado à manutenção/subversão de um costume, de uma convenção.
} 
São esses vetores acima que ajudam a construir nossa hipótese de trabalho, partindo da observação dos "modos de sentir e de formar" 4 na dramaturgia moderna do Nordeste, pois consideramos que Lourdes Ramalho reflete sobre o seu contexto cultural e histórico-social, reconstruindo-o artisticamente, via uma ambientação, estruturação discursiva e reflexão moral, que podem ser entendidas como marcas do trágico (assim podemos dizer, moderno), por meio da manifestação de aspectos atinentes a uma "estrutura de sentimento", que envolve as produções regionais. Nesta direção, vemos como os conflitos, neste texto ramalhiano, são construídos mediante uma perspectiva sobre valores do patriarcado, ${ }^{5}$ sendo estes aqui compreendidos como resíduos em conflito com a modernidade emergente, em franca oposição ao desejo de liberdade das mulheres que estão subjugadas àquela realidade (a do patriarcado) e que dão mostras da repressão presente na organização social daquela comunidade representada e da necessidade premente de desestruturá-la.

Parece-nos ser essa a noção que sustenta a formalização estética ramalhiana nas obras da década de 1970 (bastaria pensarmos na peça em tela, mas em outras como As velhas, A feira, Festa do Rosário etc.) em que o patriarcalismo "aparece como herança rural e o Estado patrimonial paulatinamente se edifica aprisionado nas teias familiares, isto é, o público permanece prisioneiro do âmbito privado” (AGUIAR, 20oo, p. 315). Também não se pode escapar de um entendimento de que a estrutura residual (e aqui estamos falando do patriarcado), conforme Raymond Williams, foi formada no passado, mesmo que ainda seja um aspecto ativo no processo cultural do presente, em que

\footnotetext{
4 Tal expressão será tomada como sinônimo de "estrutura de sentimento", tal qual cunhado por Raymond Williams $(1979,1983)$, ao elaborar uma proposta metodológica que lhe permite contrariar qualquer concepção de conteúdo prefigurado nas obras ou em dissociação às formas. Daí que "estrutura" está para os elementos que se apresentam como uma série, por meio de relações internas e específicas, cujas dinâmicas estão engendradas e em tensão; já "sentimento" marca as distintas relações dos conceitos de visão de mundo, passando pela ideologia e englobando significados e valores pelo modo como são vividos e sentidos ativamente, em um tempo, grupo cultural ou sociedade.

${ }^{5}$ Este é um conceito com ampla tradição no pensamento social de nosso país. Conforme Aguiar (200o, p. 307), podemos entender que os "clãs patriarcais [são] constituídos por uma família estendida (incluindo parentes consanguíneos, por afinidade civil, religiosa e por adoção) chefiada por um patriarca - um grande proprietário de terras - circundado por uma massa de aparentados e/ou de outros dependentes sem laços de parentesco". A questão é que o patriarcalismo brasileiro se assentou nas bases patrimoniais e na crença de que a autoridade paterna é inquestionável, até mesmo pela justiça, o que garante a sujeição dos indivíduos.
} 
experiências, significados e valores "ainda são vividos e praticados a base do resíduo cultural, bem como social - de uma instituição ou formação social e cultural anterior" (WILLIAMS, 1979, p. 125). Já as estruturas emergentes são novos significados e valores, que estão sendo continuamente criados e que podem ser relacionados com as novas práticas e novas relações estabelecidas - todavia, o aspecto residual é mais facilmente localizável “já que grande parte dele (embora não toda) se relaciona com formações sociais anteriores e fases do processo cultural, nas quais certos significados e valores reais foram gerados" (WILLIAMS, 1979, p. 126) - ou seja, como veremos adiante, a emergência de um novo ethos feminino, que se propõe a problematizar a cultura dominante (em suas demandas trágicas), é difícil de ser percebido, só vindo à tona pela análise mais alentada do enredo e das personagens.

Essas dinâmicas, que também ajudam a formalizar a regionalidade no texto, afinal, também são vetores relevantes ao efeito estético pretendido, pois, desde a primeira rubrica, já há o anúncio da atmosfera, a que estamos chamando de trágica, que envolve a casa da família Santa Rosa, tornada o espaço em que se concentra a ação:

\footnotetext{
Candeeiro aceso. [...] Passados segundos, vulto de mulher atravessa a sala, em pontas de pés e vai escutar à porta da sala. Daí a pouco, outro vulto, também feminino, transpõe igual distância e vai juntar-se ao primeiro. A luz oscila. Há em ambas as mulheres uma inquietação que as faz mudar de lugar a fim de escutar melhor, até que forte pigarrear do lado de fora leva-as a se precipitar para o interior da casa. [...] (RAMALHO, 1980, p. 84).
}

A atitude sorrateira dessas duas personagens femininas que atravessam a cena revelará a preocupação com o futuro de uma terceira, Ana Rosa. A atmosfera de tensão, implicada pelos elementos taciturnos e pelo lusco-fusco do candeeiro, aponta para o crescente medo a vista de um vir a ser dos seus próprios destinos, uma vez que elas, Paulina e Mariinha, foram responsáveis por guardar um segredo, de tal maneira corrosivo, que as leva até aquele ponto inicial da trama. Logo saberemos que aquela atmosfera é resultado da descoberta do patriarca, Julião Santa Rosa, sobre o romance (mesmo que apenas passageiro) de sua primogênita com o padre da cidade. Aos olhos do coronel, essa transgressão (para além de qualquer esfera religiosa, tendo em conta o 
celibato do padre e a virgindade da moça) é imperdoável e, como resultado (desde as primeiras linhas do texto), ele já anuncia o desenvolvimento de planos que apontam para um caminho de vingança ineludível, tendo em conta que o aludido romance não só resultou em uma gravidez, mas, pior que isso, este resultado lhe fora camuflado durante oito meses pelas mulheres da casa.

A fim de que essa história não chegasse aos ouvidos dos vizinhos e com o objetivo de preservar a honra familiar, ameaçada de ser manchada pela ação desonrada da filha desavergonhada, ele planeja e manda executar o sacerdote, encomendando a presteza dessa finalização a seus subordinados (Gumercindo e Salustino), ao custo de cinco mil réis para cada, com o que devem fugir para os rumos do Amazonas. Contudo, o pai atribui o peso de sua própria ação, além da perda financeira implicada, à filha:

JULIÃO - (Só.) Dez mil réis! É muito dinheiro! [...] (Revoltado.) - E tudo por culpa daquela infeliz! Culpa daquela desgraçada, daquela excomungada, três vezes amaldiçoada - que vai pagar bem caro o que fez! (Grita.) - Paulina! Ô Paulina! (Entra um vulto, silencioso e encolhido.) - Cadê ela? Vá chamar! Vá buscar aquela desavergonhada que eu quero ajustar as conta! Hoje ela vai me pagar o novo e o velho! (Paulina soluça, mas não se mexe.) [...] Quantas vez almofadinha alisou banco aqui? Eu num disse sempre que num tinha filha pra casar? Falo, aviso, e, quando menos espero, lá tá a desmiolada catucando o cão com vara curta! (Paulina se encolhe mais ainda e soluça alto.) - Cale a boca aí, velha maluca! Pra que num tomou cuidado em tempo? [...]. (RAMALHO, 1980, p. 90). ${ }^{6}$

As falas de Julião declaram o ódio direcionado à Ana Rosa, mas, também, às outras duas mulheres que, diante dele e de sua ira, ficam transidas de pavor. O coronel se expõe por uma fala permeada de orgulho, marcando claramente sua posição superior ao "almofadinha": a filha, criada com tanto recato e cheia de mimos, não poderia se casar com um qualquer - sob pena de ferir o rócio paterno, tão marcado pela história individual e pelo sentimento de propriedade (além dos haveres financeiros, também do corpo e da alma de todos que giram ao seu redor) em face da comunidade. Nessa cultura da honra em que as personagens convivem, a quebra dos seus vetores acaba ocasionando reações exacerbadas, e o medo suscitado nas mulheres advém do entendimento de que

\footnotetext{
${ }^{6}$ Doravante, ao nos referirmos ao texto dramatúrgico, indicaremos apenas a sigla OMA, seguida da paginação, tendo em conta que todas as citações diretas são da mesma edição.
} 
"as pessoas, principalmente os homens, estão preparados para utilizarem força física e violência, se necessário, para defender a sua própria reputação e de sua família” (GOUVEIA et al., 2013, p. 582).

O domínio sobre a casa, enquanto espaço físico e simbólico, é utilizado como concretização da supremacia do homem sobre a mulher, ou seja, não é só o poder do pai, mas o poder do homem que se discute: naquele lócus (na verdade, concretizando a sua potência restritiva em vista do domínio de suas paredes, portas e janelas) há a representação da rigidez dos patriarcas. Para a moça, a velha casa da fazenda é a materialização de um jazigo (para seu corpo vivo e para a sua memória social que o pai pretende apagar) e de uma prisão onde restará encarcerada para sempre. Ao dar as ordens para sua clausura, o patriarca declara que, para o mundo exterior, ela passa a estar morta, pois encenará seu enterro: encomenda-se um caixão, que deveria ser lacrado, sob a desculpa de que a causa da morte teria sido uma "tísica - da galopante" (OMA, p. 98), que segue para o cemitério cheio de pedras, simulando o corpo ausente.

Como podemos perceber acima, a ação já começa expondo o estado de desamparo da protagonista (sempre ausente da cena, como mostraremos, mas dinâmica e atuante nos diálogos). Este ponto de vista sobre a tessitura da ação é pertinente ao pensamento de Raymond Williams sobre a irrupção da tragédia na modernidade, pois ele indica que na tragédia tradicional teríamos o final trágico por excelência, ou seja, aquele que culmina "com o homem nu e desamparado, exposto à tempestade que ele mesmo desencadeou", contudo, haveria outra modalidade, "que na verdade começa com o homem nu e desamparado. [...]. (WILLIAMS, 2002, p. 143. Grifo nosso).7 Ou seja, esse modo de sentir e de formar corrobora os liames da, assim chamada, "catástrofe inaugural”, como definiu Jean-Pierre Sarrazac (2013), caracterizando-a como importante

\footnotetext{
7 Portanto, a compreensão de Williams (2002) sobre a tragédia moderna recai sobre um entendimento bem marcado sobre o que ele chama de uma dialética entre ordem e desordem: os indivíduos que vivem sob a égide de uma ordem, naquele caso, a capitalista, estão submetidos a um quadro de desordem (em suas múltiplas faces - desigualdade, humilhação, violência, privação, injustiça) e esperam o estabelecimento da uma nova ordem. A tragédia moderna surgiria, então, como forma artística possibilitadora da formalização estética de conteúdos sociais a partir deste princípio de generalização (a dialética entre a ordem e a desordem), a fim de se proceder a análise dos processos sociais, principalmente daqueles que implicam na manutenção da óbvia desordem, em detrimento da implantação de uma nova ordem. Por este raciocínio, podemos ler a dialética manutenção/subversão do patriarcado como trágica e, portanto, atinente à compreensão da peça em tela como uma tragédia moderna.
} 
aspecto da sua definição de trágico moderno - aquele cujos acontecimentos já estão marcados tragicamente, desde os primeiros momentos de uma peça, envolvendo as personagens e o contexto em que estão inseridas. Assim, em Os mal-amados, como demonstrado, a situação trágica está dada desde as suas primeiras linhas, sendo movida pela ocorrência de ranços de uma sociedade patriarcal revelados na defesa da honra que põe em situação de desamparo a protagonista ausente, Ana Rosa.

Paulina, lutando com as armas discursivas que pode demandar, clama pela segurança da sua filha ("Me castigue, me açoite, me mate, se quiser, mas num toque em Ana Rosa!" (OMA, p. 91)), pois a percebe já frágil e alquebrada por tudo que a circunda (“Nas condições que se acha num vai durar muito não [...] Tá se ultimando!" (OMA, p. 92)). De outro lado, para além de sua viril violência, Julião representa e defende uma falsa moral ("Tenho que acabar com essa cachorra antes que os vira-lata do mundo todo venha ganir no meu terreiro!" (OMA, p. 92)): sua decisão em levar adiante a mentira em torno da falsa morte da própria filha, na verdade artifício que atua em defesa de sua honra individual, contraditoriamente, se expõe quando ele tem a desfaçatez de propor que, dali em diante, sua afilhada Mariinha passaria a fazer-lhe companhia nas noites de solidão, enquanto à esposa sobraria o papel de babá da criança em vias de nascer. Ou seja, honra é um termo que precisa ser tomado em seus contextos de uso, pois tanto podemos tomá-lo em vista do valor autoatribuído por alguém ou do que este mesmo alguém julga ter diante da sociedade por suas formas de agir, como também no que diz da compreensão da desonra em vista dos prejuízos sociais que dela podem advir (aqui, estando implicada a honra social, menos que a honra familiar).

Assim, parece-nos correto afirmar que o conflito da peça está centrado no binômio honra/vergonha, indicando estas questões como alocadas na esfera trágica, cujo fato fundante parece ser essa preocupação do patriarca quanto a sua reputação (no caso, aquilo que diz da honra masculina, enquanto atributo individual). É evidente que, de início, o binômio referido tem que ser tomado não por oposição, mas por intercambialidade, pois, conforme Rohden (2006, p. 106), vergonha “pode ser entendida, de modo semelhante à honra, como a preocupação com a reputação ou o que faz uma pessoa sensível à pressão exercida pela opinião pública. A falta de vergonha é que se 
equipararia à desonra”. Contudo, se pensarmos sobre as questões envolvendo as personagens, conforme expusemos acima, não nos é facultado esquecer que há oposição entre aquilo que é exigido de homens e mulheres, pois

\footnotetext{
O centro da honra da família, do grupo, estaria no comportamento das mulheres, mas caberia aos homens a responsabilidade por defendê-las em ofensas públicas. A vergonha, herda-se da mãe. A honra ou direito à precedência, herda-se do pai. A primeira tenta manter-se, a segunda obriga à ação no mundo social (ROHDEN, 2006, p. 107).
}

Considerando a recorrência do fato de Julião ofender Ana Rosa, comparando-a a uma "cachorra" que atrai os vira-latas, como se houvesse a incidência sobre ela de elementos erótico-sexuais do cio animalizado, é factível afirmar que a honra masculina é colocada em primeiro lugar e que, de acordo com a visão de mundo do coronel, é esta defesa que deveria ter sido priorizada pelas mulheres da casa, pois, para ele, a preservação de seu "bom nome” estaria acima de tudo, pois garantiria a honra familiar frente à comunidade. $\mathrm{O}$ fato de estar preocupado com o que os outros irão falar - e isso só é factível para o que se torna público, bastando lembrar que seus pudores domésticos não existem - é a justificativa que o coronel usa para agir de modo tão violento para com o Padre Rafael: o ofensor estava morto, sem língua, com os olhos furados e emasculado, lavando com sangue a honra masculina de um pai desobedecido e enfrentado.

Restaria, agora, acertar as contas com a que deu espaço para que a ofensa ocorresse: Ana Rosa. Todavia, Paulina, que mantem sua honra, mesmo em face da desonra familiar que pode acometer a todos caso a situação da filha venha à tona, compreende que, falhada a tentativa de manter a ordem patriarcal, resta, ainda, a possibilidade de se manter a vergonha, afinal de contas, atributo do feminino - mesmo que, para isso, ela precisasse ser imolada no lugar da filha. À defesa da prole, no caso dessa personagem, sobrevém o seu entendimento, mesmo que ainda muito precário de que a honra de Julião não pode ser mantida sobre os escombros, inclusive de sua vida sexual e da sua extrema desvalorização na ordem doméstica, tendo em conta que ela pode ser substituída, a qualquer momento, por uma amásia, o que passa a ratificar a sua união de forças com Mariinha, sob ameaça de virar um objeto para o desfrute de um 
homem autoritário. Inclusive, Paulina é culpabilizada duplamente: por ela não ter tido a capacidade de lhe dar um filho homem, sendo chamada de "maninha" (ou seja, estéril, a despeito de ter tido uma filha, o que exibe a centralidade do valor do filho varão).

Lourdes Ramalho, então, formaliza isso no âmbito das convenções sociais e teatrais mediante a articulação dessa dialética travada entre fato social e forma estética, cabendo à Julião, como símbolo de "macheza", defender sua honra individual frente ao eixo feminino que parece esquecer o ethos negativo que lhes açambarca, quando o patriarcado não está sob a prova da comunidade. Por isso, Ana Rosa é punida por não ter conservado a sua pureza sexual, pois quando uma

\begin{abstract}
[...] mulher é desonrada, perde a vergüenza ao manchar sua pureza sexual mas um homem não. Enquanto certas formas de conduta são honrosas para ambos os sexos, o binómio honra-vergonha exige noutras esferas formas de conduta que são virtudes exclusivas de um dos sexos apenas. Obriga um homem a defender sua honra e a honra da sua família, uma mulher a conservar a sua pureza. Os conceitos de honra e vergonha porém podem entender-se até um ponto em que deixam de ser sinónimos e, nesse ponto, perdem o seu valor ético. [...] (PITTRIVERS, 1988, p. 31).
\end{abstract}

Se a vergonha só diz do ethos feminino, ela, também pode passar a ser lida, em uma direção contrária nessa peça, pelo menos inicialmente. Por desvirtuar sua "pureza” sexual, a Ana Rosa cabe pagar o preço que o patriarcado lhe cobra - o que vai ser formalizado, no âmbito temático, pelo seu encarceramento no sótão da casa e, no âmbito formal, no seu silenciamento na cena, revelando a pertinência temático-formal dessa dialética. Ao considerarmos as falas de Julião, esse fator está em evidência, uma vez que ele não quer ser visto “de cima” pela comunidade, pois, sendo quem é, seria vergonhoso ter uma filha que "não se deu o respeito". No quadro 2 da peça, podemos observar mais de perto essas relações na esfera rural onde, de um lado, está a preservação desse lugar subalterno das mulheres e, de outro, estão os compromissos sociais e fiscais atribuídos aos homens. Essa dinâmica é desenhada pelo diálogo entre Julião e Isidoro, que age como uma espécie de porta-voz dos acontecimentos que se dão fora da casa, e é a partir dele que Julião começa a espalhar os elementos que culminarão na mentira em torno da suposta morte da filha. Um deles se dá em torno de uma carta que deve seguir para a 
capital (na verdade, um bilhete escrito por Mariinha com uma falsa confissão relativa ao crime encomendado): o coronel descobre que o assunto circula de boca em boca, ao que reage dizendo que não havia nenhum segredo, ele só queria deixar reservado o fato de ter enviado correspondência a um médico sobre a situação de sua filha.

O compadre então começa a traçar um posicionamento que a nós interessa pela ambiguidade presente nessa "falsa moral”, pois, mais uma vez, a vergonha só poderia ser acionada pelos imperativos externos, pelo que os outros pensam sobre ele e sua família na comunidade, não havendo nenhuma interiorização de valores que levasse, por exemplo, à culpa, como a noção de pecado ou qualquer critério moral:

ISIDORO - Ah, compreendo, o que o compadre num queria era ver esse assunto de boca em boca... Faz muito bem, embora doença num seja vergonha - ninguém adoece por gosto. Feio seria outras coisas... Ora, isso nem se fala - só de pensar sujaria a santidade dela...

JULIÃO - O que foi que você falou?

ISIDORO - Loucuras! É o que se vê hoje em dia! Por isso é que o pai de família tem toda razão de trazer as filhas presas... Não tanto, talvez, como você, que vivia com a menina numa redoma...

$[\ldots]$

Ninguém mais sabe quem é passada ou donzela - é um tal de mulher solta pelo meio da rua, e andam tão mal forradas e num remelexo tão amolestado que revolta, compadre! (OMA, p. 103-104).

$\mathrm{Na}$ fala de Isidoro é comprovada a prevenção do patriarca, isso porque o posicionamento do compadre denota uma postura de julgamento para o modo como as mulheres agem (doença não é vergonha, mas em compensação outros comportamentos são). Ao questionar sobre o que o vizinho queria dizer com aquela menção, é possível observar que a colocação dúbia proferida por Isidoro logo é retirada diante da reação do pai aviltado, o que nos permite questionar se a honra de Ana Rosa estava assim tão preservada como julgava Julião... Ainda na fala de Isidoro, há um espanto ao dizer que, naqueles dias, não se sabe mais quem é "passada ou donzela" e que as mulheres andavam “mal forradas" e "num remelexo tão amolestado", isto é, há uma tentativa dos homens, a favor da preservação de sua honra, com a permanência dos costumes residuais em confronto ao que surge de emergente em face do comportamento das mulheres daquela esfera social. 
Contudo, em contraponto a esse caráter ressentido em torno dos ditames morais, há, na postura desses dois senhores, uma preocupação com os fatos que circundam os seus negócios. Isidoro comenta que foi intimado pelo "causo dos pesos e do algodão". Sua preocupação é motivada pelo fato de estarem sendo obrigados, pelo Conselho Municipal, a padronizarem a pesagem das mercadorias que negociam. E isso logicamente os incomoda, e interpretam como um afronte, uma vez que, no peso antigo, a medida se dava de acordo com que seria conveniente e lucrativo para os patrões, apontando que ambos não aplicam a mesma medida para as suas ações da mesma maneira como exigem das mulheres uma postura pertinente às normas morais. Isso ocorre pois o rigor utilizado nos princípios familiares tem, como oposição, a falta dessa austeridade no que toca os compromissos sociais e fiscais.

\section{Do silenciamento e das fugas}

Já afirmamos que Ana Rosa não está presente fisicamente na cena, em nenhum dos momentos da peça: ela não possui voz, está silenciada, mas suas atitudes do passado é que movem as ações. No plano temático, compreendemos que esse silenciamento encontra uma correspondência no plano formal - ela não consta, inclusive, na lista de personagens. Ao mesmo tempo, esta voz sequestrada revela um perfil feminino bastante singular naquele universo ficcional, na medida que ela não se importou com o fato de Rafael (o padre) ser comprometido com seu voto de castidade, afrontando, ao mesmo tempo, os ditames morais e religiosos. Ana Rosa não sofre com a vergonha - ela só faz sentido se confrontada à crítica coletiva, e o seu desejo e a consequência dele permanecem ocultos ao mundo externo à casa -, mas sofre a extremada violência de não poder decidir sobre si. Diante disso, encaramos este processo como algo que é localmente residual, e em resistência à incorporação do emergente, isto é, daquilo que traz novos significados, valores e práticas, a exemplo da liberdade da mulher. Se entendemos que o patriarcado, afinal, é um "discurso normativo de papeis familiares" 
(no dizer de NARVAZ; KOLLER, 2006, p. 49), não podemos olvidar que, até os dias atuais, ainda há enorme registro de casos de violência de gênero e de violação severa dos direitos humanos das mulheres por conta daquela mesma norma, a qual exerce e legitima o "controle da sexualidade, do corpo e da autonomia femininas" (NARVAZ; KOLLER, 2006, p. 50). ${ }^{8}$ E é o vislumbre dessa ação desmesurada de Julião que faz com que Paulina e Mariinha busquem rotas de fuga e resistência às situações que lhe são impostas.

Dito isso, devemos compreender esse texto a partir de dois planos: o plano temático e o plano formal, dialeticamente articulando os aspectos da vida social na releitura estética proposta pela dramaturga. Considerando o plano temático, notadamente no que se refere à ausência de Ana Rosa, inferimos que há indícios do silenciamento e opressão às mulheres acionados pela estrutura de sentimentos residual do patriarcado. Recuperando a discussão que realizamos anteriormente, tal termo é compreendido como um elemento do passado, mas que permanece como algo ativo no presente: significados e valores revividos e praticados na base do resíduo pelo âmbito cultural e social em suas bases sociais anteriores: e, assim, ainda se formalizam atitudes que tem como alicerce o patriarcado (mesmo que arquejante), mas que insistia (ou insiste) em se manter presente nas ações e atitudes das pessoas. A personagem do coronel seria, portanto, a representação desses valores: um homem rude e intolerante quanto às escolhas e vivências dos que estão ao seu redor, principalmente as mulheres, que, desde o início da peça, temem sua força de mando, representada pelo seu discurso agressivo e autoritário. O diálogo entre ele e Mariinha nos dá indícios de sua personalidade:

\footnotetext{
${ }^{8}$ Não devemos esquecer, todavia, que o tema da filha "emparedada" teve bastante aproveitamento no romance pernambucano de 1886, A emparedada da Rua Nova, de Carneiro Vilela, baseado em um fato, supostamente real, envolvendo uma jovem burguesa engravidada pelo amante. $\mathrm{O}$ romance, depois, publicado em folhetim, narra a tragédia envolvendo a família Favais, em que esposa e filha são seduzidas por um baiano ladino, levando o comerciante Jaime Favais a lavar a sua honra aviltada, mandando matar o sedutor, o que ocasiona o enlouquecimento da esposa e decreta a morte em vida da filha a quem só resta, amarrada e envolta numa mortalha, morrer atrás da parede levantada num desvão de um banheiro daquela residência, para atender ao fúnebre mando paterno.
} 
JULIÃO - (autoritário) Se assente aí. Agora puxe a cadeira pra frente que você vai ter que escrever. Vá, pegue a caneta pra transladar pra esse papel o que tá assentado nesse outro.

MARIINHA - (assustada) Eu... escrever?

JULIÃO - Num foi o que eu disse? Vamo, molhe a pena no tinteiro ou quer escrever sem tinta? Vá, vire o papel de banda - quem já viu escrever desse jeito? $[\ldots]$

MARIINHA - Num vou aguentar fazer, Padrinho... Meus nervo...

JULIÃO - Que nervo coisa nenhuma! Vou mandar pra num ser obedecido? [...] (OMA, p. 84-85).

Nesse ponto do texto, começamos a nos dar conta das intenções de Julião, pois o bilhete que ele manda a afilhada transcrever é, na verdade, uma falsa confissão de Gumercindo acerca da morte do sacerdote, fazendo parte do seu plano friamente arquitetado. Mariinha é descrita como uma agregada da casa, afilhada do casal, tratada como "moça véia", apesar de seus vinte e cinco anos. Ao saber que Gumercindo irá ser mandado embora, questiona o padrinho e esbraveja, pois ela e Gumercindo estavam, também, vivendo um romance às escondidas. Ou seja, enquanto Julião acreditava que tudo estava sob seu controle, na verdade era o contrário disso.

Percebemos que no plano formal, contrário a esse patriarcado residual revelado no plano do assunto, há um duplo movimento da peça: a ausência da fala de Ana Rosa e as rotas de fuga que são desenhadas desde o início pelas demais personagens femininas. São estas rotas que passam a funcionar como a representação temático-formal de estruturas emergentes que começam a corroer as estruturas dominantes de opressão ali formalizadas. Há uma contradição entre forma e conteúdo (a personagem central não está presente cenicamente, permanecendo fora do diálogo, este que é elemento fundamental do drama), indicando incompatibilidade em seus pressupostos e funcionando como indícios de uma crise: se essa personagem não fala sobre si e nem age na cena, contudo, ela nos é dada a conhecer mediante o que as demais personagens falam sobre ela. 9 Podemos tomar como exemplo desse procedimento os diálogos iniciais

\footnotetext{
${ }^{9}$ Em suma, essa questão nos dá indícios que o texto analisado ainda está localizado na área da, assim chamada, crise do drama, a qual se refere Szondi (2001), em que há o conflito intersubjetivo, decorrente da interação das personagens pelo meio verbal, e a ação que se passa em meio ao conflito familiar, desenvolvida no presente (mas, sofrendo reverberações do passado que se espraia sobre ele). Ao retomar esses aspectos, visamos esclarecer a presença da concepção do drama moderno na escrita ramalhiana, mais precisamente do que Szondi apresenta como um momento de transição, ou uma mudança de estilo,
} 
entre Julião e Clemente (o empregado negro, de dentro de casa): ambos se referem a Ana Rosa, tornando-a objeto da ação e figura central nas falas que delineiam a trama a partir de rememorações, portanto, elementos externos à ação cênico-dramática, esboçando o conflito através de uma epicização do passado, este em si contraditório ao tempo presente da ação. O período passado no convento, a forma rígida como Julião a criara, as proibições e impedimentos que afastavam os possíveis pretendentes da moça são os elementos temáticos centrais nas falas abaixo:

JULIÃO - [...] Se alembra daquelas novena de mês-de-maio? Daquele maria-vaicom-as-outra?

CLEMENTE - E eu me esqueço? (rindo) Era um tá estudante que, tinha chegado da capitá, todo metido a sebo... Aí ficou logo embeiçado pela menina. Que quando foi o leilão da festa, arrematou um laço de fita dos pé de Santana e mandou pra ela... (entusiasmado) Foi um labacé da molesta! Patrão ficou brabo!

[...]

JULIÃO - (Pensativo) Antes tivesse deixado! Tinha sido melhor com qualquer vagabundo... Mas eu podia lá adivinhar que a danada trazia um fogareiro aceso debaixo da saia! (OMA, p. 97).

Essa rememoração tematizada e formalizada nos diálogos, nos dá a compreensão de como era a vida de Ana Rosa: sob a ótica do pai ela é descrita como "safada", "boa pro fogo", "fubana”, “desavergonhada”, “puta”, etc.; já Clemente a descreve com um certo fascínio, tomando-a como uma "santa, como uma moça pura e bem tratada". Há, nesse sentido, a presença dos aspectos residuais de um forte imaginário do patriarcado rural, evidenciado na fala de Julião o qual, em outros momentos, acaba denotando esse modo de reificação da moça, tratada como mais um adorno da casa e não como um ser vivente e desejante, por exemplo. Em perspectiva contrária à do coronel, Clemente fala sobre Ana Rosa evidenciando a relação de classes, tendo em vista sua própria posição subalternizada, e, talvez, por isso, ele sempre esboça simpatizar com ela, tratando-a como uma boa pessoa, como uma moça "fermosa”, “a virge”.

Há, nesse sentido, uma incompatibilidade entre os dois discursos masculinos: enquanto as falas do pai revelam uma indignação sobre o fato da jovem não ter

tudo isso em meio à crise da forma do drama (em si contraditória a aspectos do eixo temático) e às tentativas da sua resolução via épica interna. 
preservado a sua pureza sexual; as falas de Clemente, por sua vez, colocam-na em um patamar de adoração e de respeito. No episódio do caixão, já mencionado, o coronel recomenda a Clemente:

JULIÃO - Apois vá encomendar o caixão. Mande cobrir todo de pano azul...

CLEMENTE - Azul da côr do céu...

JULIÃO - É, pra esconder os pecado dessa deslambida... Diga a Zé que enfeite todinha de estrela de lata doirada....

CLEMENTE - Reclamado de estela como as noite escura...

JULIÃO - Que reborde a tampa de guirlanda de flor... pra mentira ficar bem bonita.... E, quando ela passar pelo meio da rua, aquele enterro de virge... [...] (dando um murro na mesa) Virge... virge fudida, fudida, fudida! (OMA, p. 101-102).

De maneira aparentemente contraditória, Julião aciona signos que remetem a elementos religiosos. No caso da cor azul e das estrelas douradas (considerando a tradição católica), ele faz uma direta referência à Virgem Maria, a fim de forjar uma imagem ainda virginal para Ana Rosa, ou seja, aquilo que ele deseja que fique gravado no imaginário dos vizinhos, estaria representado no aparato do caixão que abrigaria, simbolicamente, uma moça pura e casta, incólume e incapaz de desencadear as armadilhas da vergonha sobre aquela, mesmo expressando sua visão de que, para ele, sua filha é uma "virge fudida”, que pôs em situação precária a honra familiar, ameaçando a ordem masculina e paterna.

Por outro prisma, e como consequência da asfixia que acomete as mulheres na peça, observarmos a construção de caminhos alternativos ao jugo do patriarcado, desde que Ana Rosa passa a mover as personagens em torno de si e de seu destino. Isso significa que na dialética forma-conteúdo há um paradoxo, pois, no paradigma do tema, ela é o objeto da ação e o patriarcado é o sujeito, o agente que toma as decisões sobre seu destino, cabendo-lhe a obediência. Contudo, no paradigma da forma, Ana Rosa passa a ser antevista como sujeito ativo, pois há uma busca pela voz feminina nas ações das personagens mulheres da peça, contrariando, portanto, o que estava dado pelo tema: o silenciamento, tratado como conteúdo prefigurado, permite observar as estruturas residuais do patriarcado (tendo Julião como seu representante) agindo sobre as mulheres, considerando Ana Rosa como um sujeito passivo que não decide e nem 
participa cenicamente das ações dramáticas; já no plano formal, as ações femininas, aos poucos, vão desenhando uma contrapartida com o que está dado tematicamente, pois elas vão se tornando agentes de seus próprios destinos... Por isso, se considerarmos o critério do drama cerrado, a peça apresentaria "defeitos", ao demandar artifícios da narração através dos diálogos das personagens para aludir a fatos que remetem ao que está fora da cena, soando como "pouco teatrais" do ponto de vista absoluto - mas, na peça, este recurso estilístico deve ser tomada enquanto emergência formal, uma vez que era necessário contextualizar e formalizar as ações atinentes a Ana Rosa, relevantes ao desenvolvimento do eixo temático.

Há, assim, uma relação travada entre o extraliterário e a representação da relação entre os indivíduos via diálogo que pode ser comprovada em Os mal-amados, pois compreendemos que os artifícios que movem Julião não estão localizados na esfera do presente da ação, mas no passado (ou seja, formalizando um princípio externo ao drama) e, com isso, este personagem tenta imobilizar Ana Rosa, cristalizando no tempo a sua reputação de moça intocada diante da sociedade, o que manteria, por contiguidade, sua honra também estabilizada em face da negação do vir a ser dos novos paradigmas. Por este prisma, é justamente o que está dado fora da casa, na vida social que emoldura a trama, que motiva as ações domésticas: ou seja, a cultura da honra.

É daí que, na primeira cena da peça, não sabemos as motivações que levam Julião e a família a se encontrarem naquele momento de tensão, pois as ações que geram o conflito estão fora do tempo da ação que se desenrola naquela sucessão de fatos: a desobediência de Ana Rosa, a gravidez e o assassinato do Padre são assuntos já encerrados, mas que ainda atuam na dinâmica das personagens e no desenrolar do conflito. Na organização formal isso se dá de modo ainda mais radical a partir da divisão do texto, justamente quando há uma passagem de tempo. Na primeira parte da peça é possível percebemos a fermentação do conflito - no fim do quadro 4, Julião afirma que, partir daquele momento, será dito que Mariinha é a mãe da criança que está prestes a nascer - como já mencionamos na seção anterior - e que "pra num ficar sem marido ainda nova, eu passo, de hoje avante, a dormir na sua camarinha..." (OMA, p. 119). Essa fala causa revolta nas mulheres que reagem: 
MARIINHA - Prefiro mil vezes morrer! O senhor é velho, um velho sujo, um velho imundo, sujo, nojento, imundo, imundo, imundo...

(Mariinha grita histericamente e Julião parte para ela, agarra-a, ela o esbofeteia, luta, grita, até que ele, soltando-a, rodopia sobre si e cai, numa convulsão).

CLEMENTE - (entra) Patrão! Que é isso, que é isso, Patrão?

PAULINA - (aproxima-se) Ele repuxou a boca como o velho pai, entronchou a cara, como o velho avô - congestou, como todos os homens da família! É correr a rua e comprar um purgante de aguardente alemã, como todos costuma tomar... é preparar a cadeira de roda, que dessa ele num se alevanta mais... (Neste momento ouve-se a caixinha de música) (OMA, p. 120-121).

É a partir desse momento que Julião passa a ser objeto da ação dramática, tendo Ana Rosa como sujeito desse comportamento na ação voltada à tessitura da resistência feminina frente aos valores patriarcais. A decadência da autoridade de Julião é evidente, pois ao convulsionar diante de todos ele passa por um processo de aviltamento do seu mandonismo naquela casa - diante da família e dos agregados, ele foi exposto a uma vergonha, a algo que contraria a sua virilidade, pondo em xeque sua honra masculina. Por mais que houvesse a tentativa de rebaixamento moral de Ana Rosa, por parte do patriarca, desde sua subida para o sótão, há uma elevação de seu ethos, que começa a se espraiar sobre as demais personagens. Ao pai, entretanto, ocorre o processo inverso, já que sofre uma queda moral e física, cuja marcação mais evidente está na passagem a que acabamos de nos referir. Assim, quando ele sucumbe, todos os presentes ouvem o sinal da caixinha de música, indicando o nascimento da criança, conforme o combinado desde o encarceramento doméstico da jovem da protagonista ausente - marcando, definitivamente, os rescaldos da ação feminina, já que o som que vem da caixinha de música (presente do amante morto) é o prenúncio da consolidação das rotas de fuga femininas em face dos estertores da ordem patriarcal.

Na segunda parte do texto, é quando se dá a chegada do Dr. Pedro Santos. O tempo avança para oito anos após o nascimento de Conceição. Mais uma vez, o imaginário da virgindade cerca Ana Rosa, pois, de acordo com Paulina, "se ela tiver essa criança em paz, vai passar o resto da vida vestida de branco, com um manto azul na cabeça" (OMA, p. 112) - o que indica o acionamento da sua imagem de Imaculada, cuja concepção (Conceição, é o nome da menina ali nascida) foi realizada sem a mancha do 
pecado, como que para, mesmo contraditoriamente, eximi-la de qualquer vestígio de culpa. ${ }^{10}$ Não podemos nos esquecer que a menina, apesar de crescer como filha de Mariinha e Gumercindo, é praticamente criada pela mãe de Clemente, ou seja, ela está mais aproximada do universo dos agregados e de um rebaixamento imputado pelas circunstâncias de seu nascimento. Saberemos por Pedro, todavia, que a menina diz por ali que uma santa a ensinou a ler e a escrever (será, então, que os da casa articulavam escapulidas de Ana Rosa para estar com a filha, pondo de novo a autoridade masculina em posição precária?). Conceição não aparece em cena, assim como a mãe, mas em uma única passagem, como rubrica, é indicado o ressoar de sua voz infantil que chama por Clemente, ao que o empregado responde: "Já vou! Num entre não! Num sabe que patrão não gosta de você? Pra que é teimosa?” (OMA, p. 131) - aquela criança é a materialização da desobediência de Ana Rosa e o espectro da desonra familiar, sendo assim, o coronel utiliza da autoridade que ainda lhe resta para mantê-la longe de sua visão.

Pedro, por sua vez, é advogado e sobrinho do padre Rafael, e sua estada na cidade é motivada pela busca de respostas acerca do caso envolvendo a morte violenta de seu tio. Nessa altura dos acontecimentos, já é possível observarmos uma postura diferente de Paulina frente às mentiras de Julião. Desenhando sua imagem de santo, homem justo e amigo próximo do padre Rafael, Julião conversa com Pedro e continua utilizando artifícios retóricos para que o advogado acredite em sua versão dos fatos:

PEDRO - (levanta-se e vai ao encontro) Salve o major Julião, a quem admiro e respeito há muitos anos!

JULIÃO - Doutor, pra que insultar um pobre velho como eu!

PEDRO - Nas mãos dos velhos é que se encontra a sabedoria e os bons ensinamentos... Não sabe como me sinto feliz em estar de um dos maiores amigos do meu falecido tio! (OMA, p. 123).

A primeira impressão que Pedro tem de Julião é esta imagem de um homem frágil, doente, que perdeu sua filha única para uma doença cruel. Nesse jogo de aparências,

\footnotetext{
${ }^{10}$ Além disso, podemos acionar as informações do senso comum sobre a nomeação a crianças cujos pais são desconhecidos: antigamente, era comum a escolha de sobrenomes para órfãos com base em características particulares de algum santo, sendo utilizado diversos sobrenomes como "da Conceição”, “dos Santos”, “de Maria”, “da Assunção” etc.
} 
percebemos que o sobrinho do padre tem as suas desconfianças sobre o ocorrido, mas precisa ludibriar o coronel para reunir as provas necessárias e comprovar quem é o verdadeiro culpado pela morte do parente. Vislumbrando as rotas de fuga, Paulina começa a soltar, em face do jovem que aparenta uma postura revolucionária, pistas da verdadeira versão dos fatos: enquanto Julião declara que o padre "era um santo de carne e osso! Dava tudo o que tinha! E a fé que tinha em Deus... nunca vi uma criatura tão crente!” (OMA, p. 124); ela suspira e, ironicamente, diz: “Ai, céu...”. Assim, os comentários de Paulina, cada vez mais reveladores, e as tentativas de Julião em reverter a situação embaraçosa, só acrescentam motivos para a desconfiança do advogado, inflamado mais ainda quando ela diz que "A mentira só impera enquanto a verdade num chega" (OMA, p. 127). São atitudes inesperadas de uma mulher que, de início, falava com medo da ameaça do marido e que tem seus ethos modificado no transcurso da ação. Com o patriarcado fragilizado, as mulheres percorrem a busca pelo lugar de fala, onde, afinal, vislumbram as mudanças vindouras.

Mesmo diante da tentativa de recusa de Julião em hospedar Pedro, houve a insistência por parte do advogado, devido ao seu plano de elucidação do crime. Sendo assim, durante essa estada, ele descobre que Mariinha foi quem escreveu a carta de confissão que seria a prova contra Gumercindo, quando pede que ela escreva uma lista de materiais que ele irá comprar na cidade - possibilitando-lhe comparar a caligrafia -, dentre os quais está o veneno para rato (a pedido de Paulina). Na sequência, ficamos sabendo que Gumercindo está nas redondezas, a fim de empreender seu acerto de contas com o coronel, por conta dos imbróglios do passado e para reaver Mariinha. Acuado, Julião decide encerrar toda aquela situação pondo fogo à casa, ao que Paulina reage: "eu preciso ficar viva - tenho que dar conta dos rato da casa” (OMA, p. 145). Nessa fala há evidências indicando que, dentre esses ratos, está o marido, corroborando, através dessa interpretação, que houve uma tomada de decisão consciente por parte da matriarca diante das estruturas não apenas da cultura da honra, mas de tudo o que o patriarcado denotava enquanto ameaça ao ser feminino. Por isso, o veneno para ratos é a possibilidade de corroer, por dentro, a dominação, usando, inclusive, se seus próprios estratagemas, como a dissimulação da vergonha e da culpa diante daquilo que é uma 
praga a ser combatida. Envenenado, Julião novamente colapsa e Paulina começa a dar ordem para que se ponha fim ao fogo e à situação: "O remédio fez efeito - morreu já o primeiro rato!" (OMA, p. 149). Há uma transfiguração de Paulina, perceptível na ação realizada e no discurso proferido: nada está acabado, pois a reação à praga é processual.

Diante do ocorrido, a mãe de Ana Rosa retira a chave do sótão do pescoço do coronel e a entrega nas mãos de Pedro. E esse ponto merece bastante atenção: a matriarca acrescenta que aquele que descobriu toda verdade seria quem faria justiça, libertando a moça enclausurada. Diante disso, devemos nos questionar sobre a motivação dessa atitude: se Paulina matara o próprio marido para salvar a todos, por que não seria digna de trazer a liberdade para Ana Rosa? Esse momento de culminância da ação abre uma reflexão sobre até que ponto há a representação de uma desestruturação plena do patriarcado nesta peça, isso porque essa atitude nos leva a compreender que Ana Rosa passa do domínio das mãos de um homem para as mãos de outro, como uma espécie de "transferência de posse" simbolizada pela chave do sótão. Estaria, então, Ana Rosa mais uma vez submetida ao mando de outro homem, quem sabe na realização de um casamento entre ela e Pedro, ou seria essa ação uma tentativa de Lourdes Ramalho compreender que, talvez, houvesse a possibilidade de um tratamento diferenciado para a mulher, díspar do que a velha ordem de Julião pregava, evidenciado pela figura progressista de Pedro? Ou, mais ainda: o que é delegado por Paulina é o poder de liberdade, mas não a posse plena, pois, afinal, agora, ela domina as artimanhas que, se necessárias, podem ser acionadas mais uma vez para desconstruir o sistema.

\section{Considerações finais}

Se a peça é marcada pelo silêncio de Ana Rosa de um lado, por outro, também vemos este silêncio movendo as demais personagens, as quais não permanecem inertes diante da opressão, traçando, para isso, rotas de fuga que possibilitam a reviravolta da ação. Sabemos que, nem sempre, tais vontades estão adequadas ao que está posto na 
esfera social, entrando em embate com os impulsos desejantes do indivíduo frente às imposições morais, ocorrendo, com isso, a manutenção de uma estrutura residual e dominante. Tais tendências acabam sendo formalizadas nas representações artísticas do Nordeste, tratando, por exemplo, dos conflitos marcados pelas relações/tensões entre homens e mulheres, sendo eles indicativos de um outro conflito, o social, que faz ecoar a voz dominadora do patriarcado rural que começa a ser silenciada diante das mudanças ocorridas em um momento de ruptura nos âmbitos históricos, políticos e econômicos, isto é, aspectos inerentes à modernidade/contemporaneidade que vê nascer, por seu turno, um patriarcado citadino.

As mulheres representadas nesta peça de Lourdes Ramalho há quarenta anos, carregam marcas de uma história própria de seu contexto, sendo obrigadas a abdicar de suas individualidades em nome dos valores que movem aquela realidade representada, como uma cultura da honra. Conforme discutimos, os aspectos do trágico acionados pela formalização daquela visão de mundo vazada em aspectos da regionalidade estão marcados pelo impulso desejante de Ana Rosa: ela sofre o castigo por questionar as normas estabelecidas através de sua vivência erótico-sexual, acionando os efeitos do trágico para todas as mulheres da fazenda Santa Rosa. Todavia, diferentemente do que viviam as personagens das tragédias gregas, na experiência trágica que vimos formalizada na peça em comento, as personagens femininas estão marcadas por uma exigência social que as oprime, mas que não as aniquila. Defendemos, em nossa argumentação, a hipótese de que, no plano temático, há a presença do silenciamento/opressão feminina, explicitado através das estruturas tirânicas de Julião. Concomitantemente, no plano formal haveria uma duplicidade pela qual a ausência cênica e da fala de Ana Rosa e as construções de rotas de fuga que são tomadas por Mariinha e Paulina mostram o modo como as figuras femininas procuram saídas, que vão configurando uma invasiva oposição à masculinidade hegemônica, cuja representação é instaurada pela moral conservadora própria daquela dada sociedade representada no texto, muito vazada pelos espectros da vergonha como uma espécie de herança feminina - o que também passa a ser questionado. 
Outro aspecto interessante do texto ramalhiano que precisa ser destacado é a presença forte da tensão travada entre a defesa da honra/vergonha e do ethos feminino em conflito com o patriarcado. Essa era, sem dúvida, uma das preocupações correntes do projeto estético de Lourdes Ramalho, atendendo também às exigências que eram próprias do seu contexto artístico. Posto isso, a regionalidade na obra deve ser lida enquanto índice de realismo, pelo qual a região é um espaço, ao mesmo tempo, referencial e simbólico, instaurando um compromisso da autora diante da representação das tensões de domínio/resistência entre gêneros, enquanto vetores de uma visão de mundo iminentemente trágica, para além de qualquer anacronismo formal, enquanto maneira de registrar de modo agudo a experiência de um Brasil, simultaneamente, moderno e arcaico.

\section{Referências}

AGUIAR, Neuma. Patriarcado, sociedade e patrimonialismo. Sociedade e Estado, Brasília, V. 15, n. 2, p. 303-330, dez. 2000.

BRANDÃO, Tania. Uma empresa e seus segredos: Companhia Maria Della Costa. São Paulo: Perspectiva: Rio de Janeiro: Petrobrás, 2009.

CHIAPPINI, Ligia. Velha praga? Regionalismo literário brasileiro. In: PIZARRO, Ana (org.). América Latina: palavra, literatura e cultura. São Paulo: Memorial da América Latina; Campina, SP: Editora da UNICAMP, 1994. p. 665-702. v.2.

FERNANDES, Nanci. Os grupos amadores. In: FARIA, João Roberto (dir.). História do teatro brasileiro, volume 2: do modernismo às tendências contemporâneas. São Paulo: Perspectiva: Edições SESCSP, 2013. p. 56-8o.

GOUVEIA, Valdiney V. et al. Preocupação com a honra no Nordeste brasileiro: correlatos demográficos. Psicologia E Sociedade, Belo Horizonte, v. 25, n. 3, p. 581-591, 2013. 
HAESBAERT, Rogério. Região, regionalização e regionalidade: questões contemporâneas. Antares: Letras e Humanidades, Caxias do Sul, n. 03, p. 01-23, jan. - jun. 2010.

NARVAZ, Martha Giudice; KOLLER, Sílvia Helena. Famílias e patriarcado: da prescrição normativa à subversão criativa. Psicologia E Sociedade, Porto Alegre, v. 18, n. 1, p. 49-55, abr. 2006.

PITT-RIVERS, John. Honra e posição social. In: PERISTIANY, John G. Honra e vergonha: Valores das sociedades mediterrânicas. 2. ed. Lisboa: Fundação Caloute Gulbenkian, 1988, p. 11-59.

RAMALHO, Maria de Lourdes Nunes. Os Mal-Amados. In: CORRÊA NETO, Alarico et. al. Teatro paraibano, hoje. João Pessoa: A União, 1980. p. 81-150.

RIBEIRO, Lucas Mello Carvalho; LUCERO, Ariana; GONTIJO, Eduardo Dias. O ethos homérico, a cultura da vergonha e a cultura da culpa. Psychê, São Paulo, v. 12, n. 22, p. 125-138, jun. 2008.

ROHDEN, Fabíola. Para que serve o conceito de Honra, ainda hoje?. Ensaio Bibliográfico, Campos, v.2, n.7, p.101-120, ago. 2006.

SARRAZAC, Jean-Pierre. Sete observações sobre a possibilidade de um trágico moderno - que poderia ser um trágico (do) quotidiano. Pitágoras 500, Campinas, v.4, p. 3-15, abr. 2013.

SZONDI, Peter. Teoria do drama moderno (1880-1950). Trad. Luiz Sérgio Repa. São Paulo: Cosac \& Naify Edições, 2001.

WILliAMS, Raymond. Tragédia Moderna. Trad. Betina Bischof. São Paulo: Cosac \& Naify, 2002.

. Drama from Ibsen to Brecht. Londres: Pelican Books, 1983.

. Marxismo e Literatura. Rio de Janeiro: Zahar, 1979.

Recebido em 16/04/2020.

Aprovado em 25/05/2020. 